\title{
UPAYA MENINGKATKAN 7K DI SEKOLAH MELALUI KEGIATAN REUSE, REDUCE, DAN RECYCLE (3R) DI SMP NEGERI 1 TEGOWANU KABUPATEN GROBOGAN TAHUN PELAJARAN 2010/2011 Oleh Hartanto
}

\begin{abstract}
Abstrak: Penelitian ini dilandasi oleh sebuah kenyataan bahwa kebersihan di SMP Negeri 1 Tegowanu Kabupaten Grobogan selama ini tidak dapat maksimal. Sampah berserakan di mana-mana. Tempat sampah yang sudah tersedia tidak dapat dimanfaatkan secara maksimal. Kamar mandi/WC siswa terlihat kotor dan bau tidak sedap. Di beberapa lokasi halaman, pekarangan, dan kebun sekolah terlihat kotor karena bekas untuk membakar sampah. Masalah yang diteliti dalam penelitian ini adalah (1) Apakah dengan program kegiatan Reuse, Reduce, dan Recycle (3R) dapat meningkatkan 7K di SMP Negeri 1 Tegowanu, dan (2) seberapa besar peningkatan 7K setelah dilaksanakan program kegiatan Reuse, Reduce, dan Recycle (3R) di SMP Negeri 1 Tegowanu. Sedangkan tujuan penelitian ini adalah (a) untuk memperoleh informasi yang akurat apakah melalui program kegiatan Reuse, Reduce, dan Recycle (3R) dapat meningkatkan 7K di SMP negeri 1 Tegowanu dan (b) untuk memperoleh informasi yang akurat mengenai besarnya peningkatan $7 \mathrm{~K}$ setelah dilaksanakannya kegiatan program kegiatan Reuse, Reduce, dan Recycle (3R) di SMP Negeri 1 Tegowanu. Desain penelitian ini adalah penelitian tindakan sekolah (PTS). Teori yang dipakai dalam penelitian ini meliputi teori-teori tentang hasil belajar, hal-hal yang mempengaruhi hasil belajar, pengertian $7 \mathrm{~K}$, pengertian $3 \mathrm{R}$ dalam pengelolaan sampah, penciptaan budaya bersih di sekolah, dan dampak lingkungan sekolah terhadap hasil belajar siswa. Penelitian berlangsung selama dua siklus. Tiap siklus terdiri atas perencanaan, pelaksanaan, observasi, dan refleksi. Data penelitian diperoleh dengan pengamatan dan wawancara. Hasil penelitian ini menunjukkan bahwa melalui kegiatan 3R (Reuse, Reduce, dan Recycle), 7K di SMP Negeri 1 Tegowanu meningkat. Peningkatan $7 \mathrm{~K}$ dari kondisi awal sampai dengan siklus I adalah sebesar 33,18\%. Sementara itu kenaikan dari siklus I ke siklus II adalah sebesar 15,45\%. Sedangkan bila dibandingkan antara kondisi awal sebelum diadakan tindakan dengan akhir siklus II adalah sebesar 48,63\%. Para siswa dan seluruh warga sekolah menjadi memiliki kebiasaan untuk hidup bersih. Berdasarkan hasil penelitian tersebut dapat disimpulkan bahwa melalui kegiatan reuse, reduce, dan recycle dapat meningkatkan 7K di SMP Negeri 1 Tegowanu. Oleh karena itu, disarankan kepada para kepala sekolah, untuk menggunakan kegiatan reuse, reduce, dan recycle dalam menciptakan sekolah yang bersih.
\end{abstract}

Kata kunci: peningkatan $7 K, 3 R$ (Reuse, Reduce, dan Recycle)

*) Kepala SMP Negeri I Tegowanu Kabupaten Grobogan 


\section{PENDAHULUAN}

\section{Latar Belakang Masalah}

Penelitian ini dilandasi oleh sebuah kenyataan bahwa kebersihan di SMP Negeri 1 Tegowanu Kabupaten Grobogan selama ini tidak dapat maksimal. Sampah berserakan di mana-mana. Tempat sampah yang sudah tersedia tidak dapat dimanfaatkan secara baik. Kamar mandi/WC siswa terlihat kotor dan berbau tidak sedap. Di beberapa lokasi halaman, pekarangan, dan kebun sekolah terlihat kotor karena bekas untuk membakar sampah.

Persoalan sampah di sekolah yang selalu menjadi persoalan yang sangat menarik untuk dibicarakan adalah sampah yang berasal berasal dari plastik. Seperti diketahui bersama bahwa di setiap sekolah akhir-akhir ini banyak sekali penjual atau pedagang yang menjajakan dagangannya di sekitar sekolah, misalnya sate pentol, siomay, bakso tusuk, dan minuman yang dibungkus dengan menggunakan plastik.

Memang saat ini plastik dirasa merupakan sarana yang praktis sebagai pembungkus makanan atau minuman. Selain mudah didapat, harganya juga murah. Para pedagang juga merasa praktis karena tidak perlu menyiapkan tempat makan atau minum (piring, gelas), mereka juga tidak perlu repot harus mencuci piring atau gelas tersebut. Para siswa juga merasa lebih praktis karena ketika mereka membeli makanan atau minuman tersebut, habis makan dan minum, plastik bekas pembungkusnya tinggal dibuang dan selesai.

Namun hal ini menimbulkan dampak buruk yang luar biasa. Pada musim kemarau sampah plastik bertebaran di mana-mana karena tertiup angin. Pada musim penghujan, samapah plastik terlihat kotor dan menjijikkan. Lebih-lebih plastik bekas pembungkus sate pentol atau siomay yang di dalamnya terdapat sisa saus. Hal ini benar-benar terlihat menjijikkan dan menimbulkan bau yang tidak sedap.

Sampah yang paling banyak adalah sampah plastik. Banyak sekali penjual atau pedagang (misalnya sate pentol, siomay, bakso tusuk, dan minuman) yang menjajakan dagangannya di sekitar sekolah dengan menggunakan plastik. Tidak 
dapat dipungkiri, bahwa plastik memang merupakan alat pembungkus yang murah, praktis, dan mudah didapat.

Petugas kebersihan sekolah sudah dibina sedemikian rupa, agar melaksanakan kebersihan secara benar. Sekolah sudah membuat pembagian tugas dan pembagian wilayah yang menjadi tugas dan tanggung jawabnya. Secara rutin kepala sekolah dan kepala urusan tata usaha telah mengadakan pembinaan kepada para petugas kebersihan sekolah tersebut. Setiap mereka melaksanakan tugas kebersihan selalu dipantau dan diawasai. Namun hasilnya tetap belum maksimal.

Di tiap-tiap kelas telah dibentuk regu kerja untuk kebersihan kelas masingmasing. Regu kerja tersebut bertugas untuk membersihkan kelasnya masing-masing, menyiapkan keperluan kelas pada hari bersangkutan, yang berkaitan dengan penyiapan alat tulis kelas (kapur, spidol, penghapus, jangka, penggaris, dan lain-lain) dan kebersihan papan tulis. Namun hal itu juga belum bisa mengatasi persoalan sampah tersebut.

Kondisi yang seperti ini sangat mengganggu pelaksanaan proses pembelajaran di sekolah. Kondisi sekolah yang seperti itu membuat para siswa tidak nyaman dalam belajar. Para gurupun merasa tidak nyaman mengelola pembelajaran dengan kondisi kebersihan yang seperti itu. Hal ini akan mengakibatkan pembelajaran tidak dapat optimal sehingga hasil pembelajaran pun juga tidak optimal. Dengan demikian dapat dikatakan bahwa kondisi kebersihan sekolah yang kurang baik menyebabkan pencapaian tujuan pembelajaran tidak maksimal.

Sementara itu Kementerian Negara Lingkungan Hidup (KNLH) bersamasama dengan Departemen Pendidikan Nasional, Departemen Agama, dan Departemen Dalam Negeri menetapkan kebijakan tentang Pendidikan Lingkungan Hidup (PLH). Kebijakan ini merupakan kebijakan dasar sebagai arahan bagi semua pemangku kepentingan dalam melaksanakan dan mengembangkan PLH di Indonesia. PLH diyakini sebagai solusi yang paling tepat untuk meningkatkan pengetahuan dan pemahaman masyarakat terhadap penyelamatan dan pelestarian lingkungan (Kementerian LH, 2010: i). 
Sebagai realisasi kebijakan tersebut, Menteri Negara Lingkungan Hidup dan Menteri Pendidikan Nasional pada tanggal 21 Februari 2006 telah mencanangkan Program Adiwiyata, yaitu sekolah peduli dan berbudaya lingkungan. Salah satu kegiatan yang dikembangkan dalam program adiwiyata tersebut adalah Reuse, Reduce, dan Recycle yang kemudian disingkat 3R. Program 3R tersebut dirasa bisa menanggulangi sampah yang berserakan di sekolah. Oleh karena itu peneliti berupaya menerapkan program $3 \mathrm{R}$ tersebut dalam menanggulangi masalah sampah di SMP Negeri 1 Tegowanu.

\section{Identifikasi Masalah}

Sampah yang menumpuk, berserakan, dan sangat mengganggu proses pembelajaran di SMP Negeri 1 Tegowanu disebabkan oleh berbagai faktor, yaitu (1) Kesadaran warga sekolah yang rendah terhadap penanganan sampah di sekolah, (2) warga sekolah belum memahami program 3R, karena program ini merupakan program baru yang dimunculkan oleh Kementerian Lingkungan Hidup, (3) para pengelola kantin sekolah dan para penjual makanan dan minuman di sekitar sekolah kurang peduli terhadap pemanfaatan plastik sebagai pembungkus makanan dan minuman, (4) belum terciptanya budaya sekolah yang mendukung terwujudnya sekolah yang bersih dan indah, dan (5) luasnya areal sekolah (2 hektar) dan minimnya petugas kebersihan (hanya 3 orang) sehingga membuat petugas kebersihan sekolah kurang mampu melaksanakan kebersihan pada areal yang luas tersebut.

\section{Cakupan Masalah}

Bertolak dari faktor penyebab sampah yang menumpuk, berserakan, dan sangat mengganggu proses pembelajaran di SMP Negeri 1 Tegowanu, salah satunya disebabkan oleh budaya sekolah yang kurang mendukung. Oleh karena itu peneliti akan mengatasi masalah sampah yang menumpuk, berserakan, dan sangat mengganggu proses pembelajaran melalui program kegiatan Reuse, Reduce, dan Recycle (3R) ini sebagai wujud budaya sekolah yang mendukung penciptaan $7 \mathrm{~K}$ di 
sekolah. Berkaitan dengan hal itu permasalahan yang diteliti dalam penelitian ini dibatasi pada upaya meningkatkan 7K di SMP Negeri 1 Tegowanu melalui kegiatan Reuse, Reduce, dan Recycle (3R). Permasalahan di luar itu tidak akan diteliti.

\section{Rumusan Masalah}

Permasalahan dalam penelitian ini adalah (1) apakah dengan program kegiatan Reuse, Reduce, dan Recycle (3R) dapat meningkatkan 7K di SMP Negeri 1 Tegowanu? (2) seberapa besar peningkatan 7K setelah dilaksanakan program kegiatan Reuse, Reduce, dan Recycle (3R) di SMP Negeri 1 Tegowanu?

\section{Tujuan Penelitian}

Tujuan penelitian ini adalah (1) untuk memperoleh informasi yang akurat apakah melalui program kegiatan Reuse, Reduce, dan Recycle (3R) dapat meningkatkan 7K di SMP Negeri 1 Tegowanu, dan (2) untuk memperoleh informasi yang akurat mengenai besarnya peningkatan $7 \mathrm{~K}$ setelah dilaksanakannya kegiatan program kegiatan Reuse, Reduce, dan Recycle (3R) di SMP Negeri 1 Tegowanu.

\section{Manfaat Penelitian}

Manfaat penelitian ini dibedakan menjadi empat hal, yaitu manfaat bagi sekolah, bagi guru, bagi siswa, dan bagi masyarakat. (1) Bagi Sekolah manfaat penelitian ini adalah pelaksanaan $7 \mathrm{~K}$ di sekolah meningkat, sehingga dapat menunjang keberhasilan pencapaian tujuan pembelajaran, (2) Manfaat penelitian ini bagi guru adalah para guru merasa lebih nyaman, senang, dan tenang dalam mengelola pembelajaran, kondisi ini membuat para guru dan siswa merasa enjoy sehingga proses belajar mengajar menjadi maksimal, (3) penelitian ini bagi siswa adalah mereka menjadi kerasan dan betah belajar di sekolah. Mereka bisa belajar secara optimal tanpa diganggu oleh kondisi sampah yang berserakan, kotor, dan bau, (4) bagi masyarakat, hasil penelitian ini bermanfaat untuk meningkatkan 
dukungannya terhadap sekolah. Mereka merasa bangga dengan keberadaan sekolah yang bersih, sehingga rasa memiliki sekolah bagi masyarakat akan meningkat.

\section{KERANGKA TEORETIS DAN KAJIAN PUSTAKA}

\section{Landasan Teori}

\section{Faktor-faktor yang Mempengaruhi Hasil Belajar}

Hasil belajar merupakan keseluruhan pola perilaku, baik berupa kognitif, afektif, maupun psikomotorik dan merupakan kesatuan yang diperoleh peserta didik setelah mengikuti proses belajar pada suatu periode tertentu. Hal ini sejalan dengan yang dikemukakan oleh Burhanudin (1990:65) yang mengemukakan bahwa hasil belajar siswa berhubungan dengan tingkat atau hasil yang dicapai siswa dalam mengetahui, memahami, menyikapi atau menguasai suatu pengetahuan dalam materi tertentu menurut ukuran yang ditetapkan, baik ukuran yang bersifat kongkret berupa nilai hasil belajar maupun yang bersifat abstrak berupa perilaku yang ditampilkan oleh siswa.

Selanjutnya secara lebih jelas dan lengkap Sukmadinata (1997:124) mengemukakan bahwa hasil belajar merupakan segala perilaku yang dimiliki siswa sebagai akibat dari proses belajar yang ditempuhnya, meliputi semua akibat dari proses belajar yang berlangsung di sekolah atau di luar sekolah, yang bersifat kognitif, afektif, dan psikomotorik yang disengaja maupun tidak disengaja.

Nana Sudjana (1989:45) mengemukakan bahwa hasil belajar siswa terbagi menjadi tiga macam, yaitu (1) keterampilan dan kebiasaan, (2) pengetahuan dan pengertian, dan (3) sikap dan cita-cita. Selanjutnya Arikunto (1996:105) mengidentifikasi indikator hasil belajar siswa terdiri atas nilai harian, nilai ulangan umum, nilai tugas-tugas, cara menjawab pertanyaan di kelas, nilai ketelitian catatan, pembuatan laporan, ketekunan, keuletan, dan usaha.

Sedangkan dalam Permendiknas Nomor 20 Tahun 2007 tentang Standar Penilaian disebutkan bahwa penilaian hasil belajar siswa dilakukan oleh tiga komponen, yaitu (1) penilaian oleh pendidik, (2) penilaian oleh satuan pendidikan, 
dan (3) penilaian oleh pemerintah. Penilaian oleh pendidik meliputi penilaian harian yang berupa tugas-tugas, portofolio, dan ulangan harian. Penilaian oleh satuan pendidikan meliputi penilaian ulangan tengah semester, penilaian akhir kelompok mata pelajaran, ulangan akhir semester, ulangan kenaikan kelas, dan ujian akhir sekolah. Sedangkan penilaian oleh pemerintah berupa pelaksanaan Ujian Nasional atau yang sering disingkat UN.

Berdasarkan teori-teori tentang faktor-faktor yang mempengaruhi hasil belajar siswa tersebut, dapat dikemukakan bahwa terdapat dua faktor dominan. Kedua faktor dominan itu adalah internal dan eksternal. Hal-hal yang berkaitan dengan faktor eksternal di antaranya adalah sarana prasarana dan kondisi sosial lingkungan belajar siswa.

Kondisi sarana prasarana dan lingkungan belajar siswa sangat mempengaruhi hasil belajar siswa. Sarana prasarana di sekolah yang memadai sangat mendukung pencapaian hasil belajar siswa yang maksimal. Demikian pula lingkungan sekolah yang bersih, indah, sejuk, asri, nyaman membuat siswa dan guru nyaman untuk belajar. Kondisi yang demikian sangat mendukung penapaian hasil belajar siswa.

\section{Pengertian 7K}

Secara umum sekolah-sekolah telah memiliki program 7K. Hal itu diprogramkan oleh sekolah sebagai upaya untuk menciptakan lingkungan sekolah yang bersih, indah, dan nyaman untuk pelaksanaan proses pembelajaran. Sebab sekolah yang bersih, indah, dan nyaman sangat mendukung pencapaian tujuan pembelajaran yang dikelola oleh sekolah bersangkutan. Bahkan tidak hanya di sekolah-sekolah, kantor-kantor pemerintah maupun swasta juga mencanangkan program $7 \mathrm{~K}$ ini.

7K merupakan singkatan dari Ketertiban, Keindahan, Kebersihan, Keamanan, Kekeluargaan, Kerindangan, dan Kedisiplinan. Program ini dimaksudkan agar siswa mempunyai kebiasaan-kebiasaan yang baik. Berperilaku sopan, tidak membuang 
sampah sembarangan, selalu menjaga kebersihan lingkungan, kedislipinan, dan lainlain adalah aspek-aspek yang dikembangkan di program ini.

\section{Pengertian 3R}

3R merupakan singkatan dari reuse, reduce, dan recycle. Reuse berarti menggunakan kembali sampah yang masih dapat digunakan untuk fungsi yang sama ataupun fungsi lainnya. Reduce berarti mengurangi segala sesuatu yang mengakibatkan sampah. Dan Recycle berarti mengolah kembali (daur ulang) sampah menjadi barang atau produk baru yang bermanfaat. Mengelola sampah dengan sistem 3R (Reuse Reduce Recycle) dapat dilakukan oleh siapa saja, kapan saja (setiap hari), di mana saja, dan tanpa biaya. Yang dibutuhkan hanya sedikit waktu dan kepedulian kita.

Selanjutnya Darmawan (2010:1) menjelaskan bahwa Reduce berarti kita mengurangi penggunaan bahan-bahan yang bisa merusak lingkungan. Reduce juga berarti mengurangi belanja barang-barang yang anda tidak "terlalu" butuhkan seperti baju baru, aksesoris tambahan atau apa pun yang intinya adalah pengurangan kebutuhan. Kurangi juga penggunaan kertas tissue dengan sapu tangan, kurangi penggunaan kertas di kantor dengan print preview sebelum mencetak agar tidak salah, baca koran online, dan lainnya.

Reuse sendiri berarti pemakaian kembali seperti contohnya memberikan bajubaju bekas anda ke yatim piatu. Tapi yang paling dekat adalah memberikan baju yang kekecilan pada adik atau saudara anda, selain itu baju-baju bayi yang hanya beberapa bulan dipakai masih bagus dan bisa diberikan pada saudara yang membutuhkan.

Recycle adalah mendaur ulang barang. Paling mudah adalah mendaur ulang sampah organik di rumah anda, menggunakan bekas botol plastik air minum atau apapun sebagai pot tanaman, sampai mendaur ulang kertas bekas untuk menjadi kertas kembali. Daur ulang secara besar-besaran belum menjadi kebiasaan di Indonesia. Tempat sampah yang membedakan antara organik dan non-organik saja tidak jalan. Malah akhirnya lebih banyak gerilyawan lingkungan yang melakukan 
daur ulang secara kreatif dan menularkannya pada banyak orang dibandingkan pemerintah.

3R atau Reuse, Reduce, dan Recycle sampai sekarang masih menjadi cara terbaik dalam mengelola dan menangani sampah dengan berbagai permasalahannya. Penerapan sistem 3R atau reuse, reduce, dan recycle menjadi salah satu solusi pengelolaan sampah di samping mengolah sampah menjadi kompos atau meanfaatkan sampah menjadi sumber listrik (PLTSa; Pembangkit Listrik Tenaga Sampah). Justru pengelolaan sampah dengan sistem 3R (Reuse Reduce Recycle) dapat dilaksanakan oleh setiap orang dalam kegiatan sehari-hari (Alamendah, 2010:1).

\section{Dampak Lingkungan Sekolah terhadap Hasil Belajar Siswa}

Semboyan yang berarti di dalam tubuh yang sehat terdapat jiwa yang sehat menjadi inspirasi penulis untuk mengkaji dampak lingkungan sekolah yang sehat terhadap hasil belajar siswa. Kesehatan tubuh siswa tidak hanya dipengaruhi oleh pola makan dan olah raga yang dilakukan siswa, tetapi juga kesehatan lingkungan tempat tinggal siswa (Fasya, 2010:1).

Diasumsikan lingkungan sekolah yang sehat, nyaman, dan kondusif berkorelasi dengan prestasi siswa. Hal ini dikarenakan proses belajar mengajar memerlukan kondisi psikologis yang mendukung. Proses belajar mengajar memerlukan ruang dan lingkungan pendukung yang dapat membantu siswa dan guru agar dapat berkonsentrasi dalam belajar. Jika para siswa belajar dalam kondisi menyenangkan dengan kelas yang bersih, udara bersih, dan sedikit polusi suara, niscaya siswa dapat belajar dengan tenang sehingga tingkat prestasi siswa juga akan naik.

Sekolah yang sehat adalah sekolah yang memiliki halaman luas. Halaman yang rindang, hijau, sejuk, indah, dan bersih. Halaman sekolah dapat dimanfaatkan sebagai sarana pengembangan prestasi siswa dalam bidang olah raga atau pun ekstrakurikuler. Selain itu, halaman sekolah dapat dijadikan sebagai sarana belajar out door dan tempat refreshing siswa. 
Komponen sehat mencakup 5 aspek yaitu sehat secara fisik, psikis, sosial, dan spiritual. Untuk itu, disusun kriteria utama dari sekolah sehat yaitu adanya program pendidikan dan pelayanan kesehatan (health education and treatment), makanan sehat (healthy eating), pendidikan olahraga (physical activity), pendidikan mental (emotional health and well being) serta program lingkungan sekolah sehat dan aman (safe and healthy environment). Jika suatu sekolah telah melaksanakan 5 kriteria tersebut di atas secara integratif dan berkesinambungan maka bisa dikatakan bahwa sekolah tersebut memenuhi standar sekolah sehat (Yulistyowati, 2010:2).

Pada saat istirahat, para siswa tentunya memerlukan lingkungan pekarangan sekolah yang nyaman, bersih, dan cukup pepohonan. Sarana refreshing siswa sejenak setelah mengikuti proses kegiatan belajar mengajar. Tempat yang nyaman, teduh, dan udara yang segar untuk menghilangkan rasa penat. Halaman sekolah yang rindang, dapat dimanfaatkan sebagai sarana belajar secara langsung (out door). Guru kreatif akan memanfaatkan lahan sebagai sarana belajar siswa secara langsung. Dengan belajar secara langsung, siswa akan mendapatkan pengalaman belajar.

Semakin pesatnya pertumbuhan kota menyebabkan pepohonan rindang habis ditebangi untuk dijadikan bangunan, terlebih jika harga tanah ikut melonjak naik. Inilah yang menjadikan jumlah oksigen berkurang. Oksigen adalah salah satu pendukung kecerdasan anak. Kadar oksigen yang sedikit pada manusia akan menyebabkan suplai darah ke otak menjadi lambat, padahal nutrisi yang kita makan sehari-hari diedarkan darah ke seluruh tubuh kita. Karena itulah dibutuhkan banyaknya pohon rindang di lingkungan sekolah sebagai paru-paru lingkungan.

Sistem sanitasi yang baik adalah syarat terpenting sebuah lingkungan layak huni. Dengan sistem sanitasi yang bersih, maka seluruh warga sekolah akan dapat lebih tenang dalam mengadakan proses belajar mengajar. Selain itu diperlukan juga sistem sumur resapan air untuk mengaliri air hujan agar tidak menjadi genangan air yang dapat menjadikan kotor lingkungan sekolah, atau bahkan membahayakan apabila didiami oleh jentik-jentik nyamuk. 
Bangunan sekolah yang kokoh akan membuat siswa merasa tenang dalam belajar. Seperti yang sering kita lihat di TV, akhir-akhir ini banyak bangunan siswa yang roboh. Baik karena usia ataupun karena kualitas bangunan yang kurang bagus. Tentunya kondisi gedung sekolah membawa dampak negatif bagi siswa. Siswa tidak akan tenang dalam belajar. Selain itu, sekolah yang bagus adalah sekolah yang dilengkapi dengan fasilitas-fasilitas yang menunjang, di antaranya adalah laboratorim dan multimedia. Dengan tersedianya hal di atas, siswa akan bersemangat belajar. Dengan demikian prestasi belajar di sekolah tidak hanya dipengaruhi oleh bagaimana anak-anak giat belajar dan dapat memahami pelajaran di sekolah, tapi juga kondisi lingkungan sekolahnya yang mendukung. Lingkungan sekolah yang nyaman dan bersih dapat mendukung tumbuh kembang anak secara optimal, anak-anak menjadi lebih sehat dan dapat berpikir secara jernih, sehingga dapat menjadi anak-anak yang cerdas dan kelak menjadi sumber daya manusia yang berkualitas.

Prestasi belajar di sekolah tidak hanya dipengaruhi oleh bagaimana anak-anak giat belajar dan dapat memahami pelajaran di sekolah, tapi juga kondisi lingkungan sekolahnya yang mendukung. Lingkungan sekolah yang nyaman dan bersih dapat mendukung tumbuh kembang anak secara optimal, anak-anak menjadi lebih sehat dan dapat berpikir secara jernih, sehingga dapat menjadi anak-anak yang cerdas dan kelak menjadi sumber daya manusia yang berkualitas

\section{Penciptaan Budaya Bersih di Sekolah}

Berbicara mengenai penciptaan budaya bersih di sekolah yang berada di wilayah kabupaten Grobogan, tidak dapat dilepaskan dari dinas yang menangani kesehatan dan kebersihan di tingkat kabupaten, yaitu Dinas Kesehatan. Dikatakan demikian karena sekolah-sekolah merupakan wilayah binaan dinas kesehatan tersebut dalam rangka menupayakan masyarakat di seluruh wilayah kabupaten memiliki derajat kesehatan yang tinggi. Hal ini sejalan dengan visi dan misi yang diemban oleh dinas kesehatan kabupaten tersebut. 
Visi Dinas Kesehatan Kabupaten Grobogan adalah "Menjadi Institusi Terdepan dan Profesional dalam Mewujudkan Grobogan Sehat". Sedangkan misinya adalah (1) merumuskan kebijakan dan memantapkan manajemen untuk meningkatkan kinerja pelayanan kesehatan, (2) menyelenggarakan pembinaan dan pelayanan kesehatan secara merata, terjangkau dan bermutu bagi seluruh masyarakat, (3) mengembangkan sistem informasi kesehatan yang akurat untuk menunjang sistem perencanaan dan evaluasi pembangunan kesehatan, (4) meningkatkan mutu sumberdaya kesehatan melalui pengembangan profesionalisme tenaga kesehatan, (5) mewujudkan kondisi lingkungan yang sehat dan perilaku hidup sehat dalam rangka mengendalikan dan mencegah penyakit menular dan penyakit tidak menular, (6) meningkatkan peran serta masyarakat dan swasta dalam penyelenggaraan pembangunan kesehatan, dan (7) meningkatkan derajat kesehatan keluarga melalui peningkatan kesadaran dalam pemeliharaan lingkungan, perbaikan gizi, peningkatan kesehatan remaja dan usia lanjut (Dinas Kesehatan Kabupaten Grobogan, 2010).

Untuk mencapai visi dan misi tersebut, salah satunya dicapai melalui program Pembiasaan Perilaku Hidup Bersih dan Sehat (PHBS) bagi masyarakat. Pembiasaan perilaku hidup bersih dan sehat dimulai dari sekolah. Dikatakan demikian karena (1) para siswa di sekolah merupakan manusia muda, masih panjang jangkauannya, masih panjang usianya, sehingga memiliki manfaat yang tinggi, (2) sekolah merupakan tempat belajar berbagai ilmu, sangat tepat untuk belajar pembiasaan PHBS, dan (3) para siswa rata-rata rmasih muda, masih mudah untuk belajar dan masih mudah untuk dibiasakan.

\section{Penelitian Terdahulu}

Penelitian mengenai penerapan 3R (Reuse, Reduce, dan Recycle) untuk meningkatkan pelaksanaan 7K (Ketertiban, Keindahan, Kebersihan, Keamanan, Kekeluargaan, Kerindangan, dan Kedisiplinan) di sekolah menurut pengamatan peneliti belum pernah dilakukan oleh peneliti lain. Oleh karena itu peneliti berharap semoga penelitian ini dapat memberikan inspirasi kepada peneliti lain untuk mengadakan penelitian serupa. 


\section{Kerangka Berpikir}

Masalah sampah yang menumpuk, berserakan, dan sangat mengganggu proses pembelajaran diduga belum terciptanya budaya sekolah dalam mengatasi pengelolaan sampah. Berdasarkan hasil diskusi secara kolaboratif untuk mengatasi hal tersebut diatas peneliti mengambil tindakan yaitu menerapkan 3R (Reuse, Recycle). Dalam menerapkan 3R peneliti bagi menjadi 2 siklus, sebagai berikut.

Siklus I : Menerapkan 3R dengan cara membuat kebijakan sekolah yang berupa: (1) seluruh warga sekolah kalau membeli makanan atau minuman harus membawa wadah/tempat sendiri; (2) para pengelola kantin dan penjual makanan/minuman di lingkungan sekolah dilarang menggunakan plastik sebagai pembungkus makanan atau minuman; (3) para pengelola kantin dan penjual makanan/minuman di lingkungan sekolah dilarang melayani siswa dan guru yang tidak membawa piring atau gelas sendiri.

Siklus II : Menerapkan 3R dengan melaksanakan tindakan siklus I ditambah dengan (1) mengontrol siswa yang tidak memiliki piring/gelas sendiri dan (2) melibatkan para pengelola kantin dan penjual makanan/minuman di lingkungan sekolah untuk ikut melakukan kebersihan sehabis waktu istirahat sekolah.

Beranjak dari konteks ini, bahwa melalui penerapan 3R upaya peningkatan 7K di sekolah dapat memenuhi harapan. Untuk lebih jelasnya kerangka berpikir dalam penelitian ini dapat digambarkan pada bagan berikut ini. 


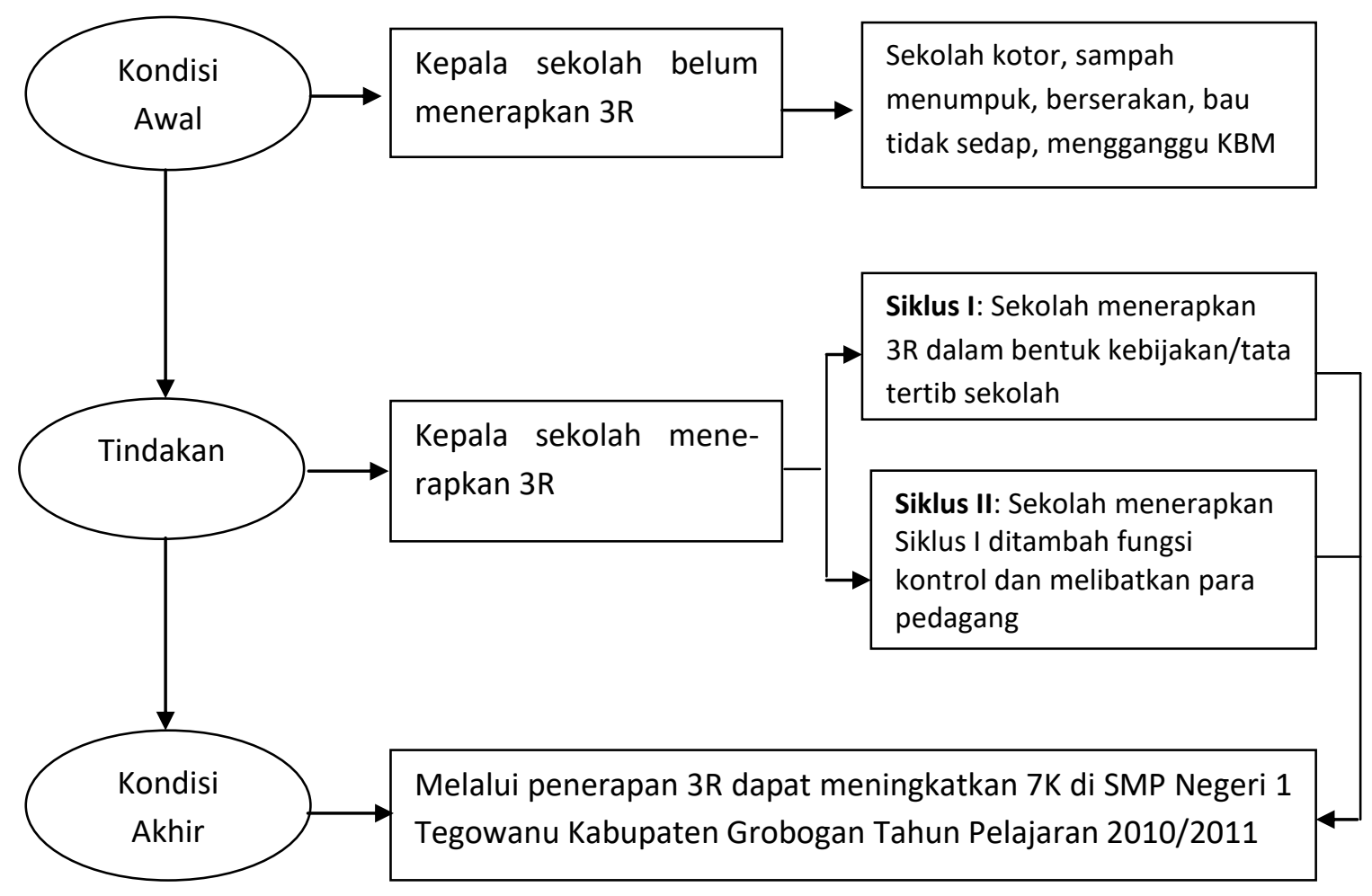

Berdasarkan gambar tersebut menunjukkan bahwa pada kondisi awal kepala sekolah atau peneliti belum menerapkan 3R, sekolah dalam keadaan kotor, banyak sampah berserakan, bau, dan mengganggu KBM. Menyadari akan hal tersebut kemudian dilakukan tindakan dengan menerapkan 3R, baik pada siklus I maupun II. Selanjutnya pada kondisi akhir kondisi sekolah terutama berkenaan dengan 7K sudah meningkat.

\section{Hipotesis Tindakan}

Hipotesis merupakan dugaan sementara yang kebenarannya perlu dibuktikan melalui proses penelitian yang ilmiah. Berdasarkan konsep tersebut, maka hipotesis tindakan dalam penelitian ini adalah melalui penerapan 3R dapat meningkatkan $7 \mathrm{~K}$ di SMP Negeri 1 Tegowanu Kabupaten Grobogan Tahun Pelajaran 2010/2011. 


\section{METODOLOGI PENELITIAN}

\section{Seting Penelitian}

Waktu penelitian ini dilakukan selama lima bulan, mulai bulan Juli sampai dengan November 2010 atau pada tahun pelajaran 2010/2011. Pemilihan waktu tersebut disesuaikan dengan kebutuhan pembelajaran yang berkaitan dengan peningkatan $7 \mathrm{~K}$ di sekolah. Kegiatan yang dilakukan pada waktu tersebut berkaitan dengan penyusunan bab I sampai dengan III, penyusunan instrumen penelitian, pelaksanaan tindakan yang terdiri dari 2 siklus, analisis data, pembuatan bahasan, simpulan dan saran serta penyusunan laporan secara keseluruhan.

Penelitian ini dilakukan di SMP Negeri 1 Tegowanu Kabupaten Grobogan. Pemilihan tempat tersebut dikarenakan peneliti merupakan guru sekaligus sebagai kepala sekolah di sekolah tersebut, sehingga secara teknis dan operasional memberikan kemudahan. Selain itu juga memberikan manfaat langsung kepada penulis dalam meningkatkan pelayanan pembelajaran melalui penyediaan tempat yang bersih, asri, indah dan nyaman.

\section{Subjek Penelitian}

Subjek penelitian ini adalah peningkatan 7K (Ketertiban, Keindahan, Kebersihan, Keamanan, Kekeluargaan, Kerindangan, dan Kedisiplinan) di SMP Negeri 1 Tegowanu melalui penerapan 3R (Reuse, Reduce, dan Recycle). Dengan meningkatnya $7 \mathrm{~K}$ diharapkan dapat meningkatkan kualitas pembelajaran.

\section{Sumber Data}

Data penelitian ini adalah kondisi sekolah yang dilihat dari segi $7 \mathrm{~K}$, terutama faktor kebersihan. Sumber data diambil dari para siswa, guru, para pedagang makanan dan minuman di sekitar sekolah, para pengelola kantin, dan komite sekolah. 


\section{Teknik dan Alat Pengumpulan Data}

Data penelitian ini dikumpulkan melalui teknik pengamatan dan wawancara. Alat pengumpulan data berupa pedoman pengamatan dan pedoman wawancara. Dari pedoman pengamatan dan pedoman wawancara tersebut dikembangkan menjadi instrumen pengamatan dan lembar wawancara.

Komponen yang diamati dalam penelitian ini adalah (1) kebersihan, (2) pemanfaatan tempat sampah, (3) pembiasaan guru dan siswa, (4) pengolahan sampah, (5) hasil pengolahan sampah, dan (6) persentase sampah yang diolah. Demikian pula dengan kegiatan wawancara, materi yang menjadi kajian wawancara adalah mataerimateri seputar komponen pengamatan tersebut.

\section{Validasi Data}

Untuk mendapatkan data valid dan terpercaya, maka dilakukan validasi data yaitu dengan cara mengkonfirmasikan data yang telah diperoleh kepada pihak-pihak yang berkepentingan, misalnya siswa, guru, pedagang makanan dan minuman di sekitar sekolah, dan komite sekolah yang juga dijadikan sebagai kolaborator penelitian.

\section{Analisis Data}

Data yang telah terkumpul dianalisis secara kuantitatif dan kualitatif. Analisis kuantitatif dilakukan untuk menghitung skor keberhasilan tindakan penelitian pada siklus I dan siklus II. Analisis kualitatif dilakukan untuk melihat kemajuan atau perbedaan kondisi 7K di sekolah, khususnya faktor kebersihan sekolah, dari hasil pengamatan. Untuk analisis data secara kuantitatif, data diolah dengan menggunakan rumus seperti berikut ini.

$$
\text { Nilai Akhir }=\frac{\text { Skor Perolehan }}{\text { Skor Maksimum }} \times 100
$$


Sedangkan untuk analisis data secara kualitatif, data diolah dengan mengamati, membandingkan kondisi, menyimpulkan kondisi 7K di SMP Negeri 1 Tegowanu setelah diberi perlakuan atau tindakan $3 R$.

\section{Indikator Kinerja}

Indikator kinerja yang ditetapkan dalam penelitian ini adalah (1) secara kuantitatif terjadinya penngkatan $7 \mathrm{~K}$ di sekolah, khususnya faktor kebersihan sekolah dari siklus I dan siklus II sebesar 25\% dan (2) secara kualitatif sekolah terlihat lebih bersih dari kondisi sebelum ada tindakan, sudah tidak lagi sampah yang menumpuk, berserakan, dan mengganggu proses pembelajaran.

\section{Prosedur Penelitian}

Desain penelitian yang digunakan dalam penelitian ini adalah penelitian tindakan sekolah (PTS). PTS adalah tindakan ilmiah yang dilakukan kepala sekolah untuk memecahkan masalah di sekolah yang dibinanya (Hopkins,2008). Ciri utama PTS adalah melakukan tindakan nyata untuk memperbaiki keadaan sekolah yang berfokus pada peningkatan mutu pembelajaran oleh guru yang mampu menghasilkan siswa kreatif, inovatif, mampu memecahkan masalah, dan berpikir kritis.

Penelitian ini dilaksanakan dalam beberapa siklus. Tiap-tiap siklus terdiri atas empat komponen yaitu perencanaan, tindakan, observasi, dan refleksi. Prosedur pelaksanaan penelitian tindakan sekolah dapat dilihat pada bagan berikut. 
SIKLUS I

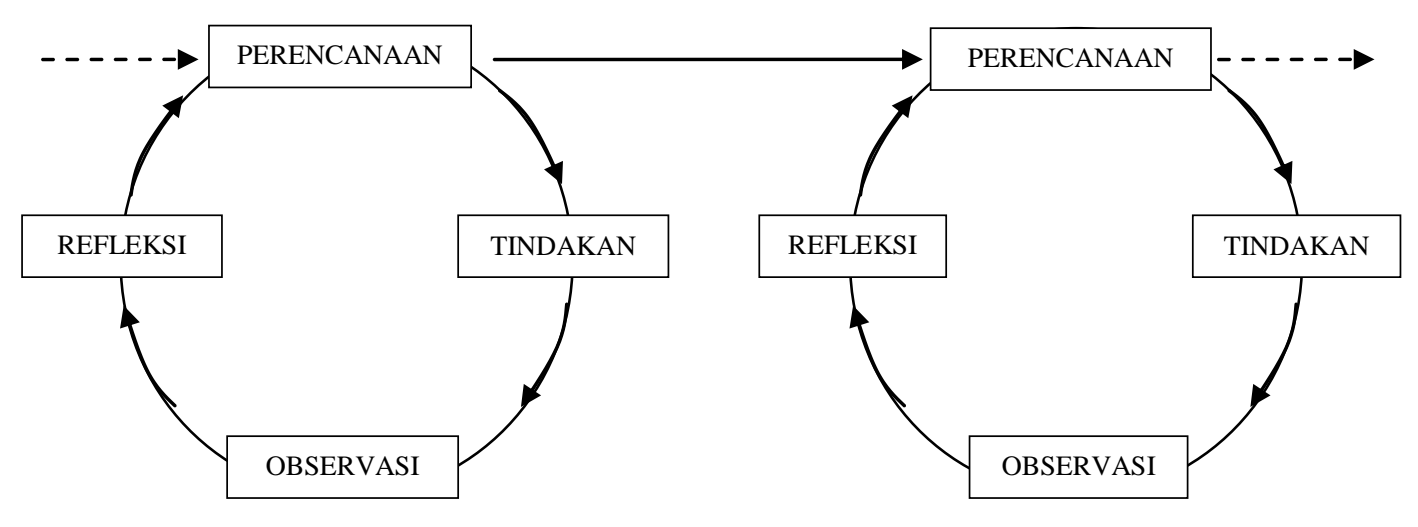

Bagan 3.1: Diagram Desain Siklus Penelitian (Subyantoro 2009:27)

Berdasarkan bagan tersebut, dapat dikemukakan bahwa penelitian ini berlangsung dalam dua siklus, yaitu siklus I dan siklus II. Tiap-tiap siklus terdiri atas empat tahap, yaitu perencanaan, tindakan, observasi, dan refleksi. Observasi awal dilakukan sebelum melaksanakan keempat tahap tersebut supaya dapat diketahui kondisi kebersihan sekolah pada tahap awal. Dengan melihat hasil refleksi awal, tindakan yang digunakan adalah melalui siklus-siklus sebagai

\section{HASIL PENELITIAN}

\section{Deskripsi Kondisi Awal}

Pengamatan kondisi 7K di SMP Negeri 1 Tegowanu Kabupaten Grobogan dilaksanakan oleh peneliti dan berkolaborasi dengan 3 orang guru. Jumlah pengamat adalah 4 orang, yang terdiri atas peneliti dan 3 guru. Hasil penelitian menunjukkan bahwa pada kondisi awal, kondisi kebersihan yang dikaitkan dengan pengelolaan sampah memperoleh skor 35,5 dari total skor 110. Setelah dihitung maka memperoleh nilai 32,27. Komponen yang memperoleh skor tertinggi hanyalah pada komponen kebersihan. Itu saja hanya pada kebersihan kelas dan memperoleh skor 
3,5. Komponen-komponen yang lain juga masih memperoleh skor minimal, yaitu masing-masing memperoleh skor 1.

\section{Deskripsi Hasil Siklus I}

\section{Perencanaan}

Pada tahap ini peneliti melakukan persiapan-persiapan yang berhubungan dengan hal-hal sebagai berikut.

1) Menyusun rencana kegiatan tindakan, yang berupa penyiapan perangkat penelitian dan persiapan sosialisasi.

2) Mengadakan sosialisasi terhadap para siswa, guru, dan keluarga besar sekolah tentang pelaksanaan tindakan tersebut.

3) Mengundang para pedgang yang menjual makanan/minuman di sekitar sekolah dan mengundang para pengelola kantin sekolah untuk diberikan sosialisasi tentang program $3 \mathrm{R}$ dan tata tertib sekolah.

4) Menyediakan sarana prasarana yang diperlukan sekolah, seperti pemenuhan tempat sampah terpilah dan penyediaan tempat pembuangan akhir sampah.

\section{Tindakan}

Pada tahap ini peneliti melakukan tindakan penelitian atau action research yang berupa, yaitu melaksanakan kebijakan atau tata tertib sekolah yang berupa penerapan 3R dalam pengelolaan sampah.

\section{Observasi}

Pada tahap ini peneliti mengadakan observasi mengenai hal-hal seperti berikut ini.

1) Mengamati para siswa dan guru dalam menjaga kebersihan pada seluruh sudut sekolah.

2) Mengamati para siswa dan guru dalam memanfaatkan tempat sampah terpilah 
3) Mengamati pembiasaan guru dan siswa dalam hal membuang sampah, memungut sampah yang tercecer, membeli makanan atau minuman dengan membawa wadah/tempat sendiri, dan pembiasaan tidak membuang sampah sembarangan.

4) Mengamati keterlaksanaan pengolahan sampah organik dan anorganik

5) Mengamati hasil pengolahan sampah

6) Mengamati persentase jumlah sampah yang terola

Hasil observasi siklus I menunjukkan bahwa pada akhir siklus I, kondisi kebersihan yang dikaitkan dengan pengelolaan sampah memperoleh skor 71,5 dari total skor 110. Setelah dihitung maka memperoleh nilai akhir 65,91. Komponen yang memperoleh skor tertinggi adalah komponen kebersihan dan komponen pemanfaatan tempat sampah. Komponen yang sangat rendah skornya adalah komponen pembiasaan guru dan siswa. Untuk komponen pengolahan sampah, komponen hasil pengolahan sampah dan komponen persentase sampah yang diolah telah mengalami peningkatan.

\section{Refleksi}

Dari hasil pengamatan terhadap kondisi awal dibandingkan dengan hasil pengamatan pada siklus I, kondisi 7K SMP Negeri 1 Tegowanu menunjukkan bahwa secara umum telah terjadi peningkatan $7 \mathrm{~K}$ antara kondisi awal dan pada kondisi akhir siklus I. Secara statistik, kenaikan tersebut adalah sebesar 33,18\%. Ini merupakan kenaikan yang luar biasa, dari target semula yang hanya $25 \%$.

Namun ada beberapa komponen yang masih memperoleh skor rendah, meskipun telah terjadi sedikit kenaikan. Komponen tersebut adalah komponen pembiasaan siswa dan guru, serta komponen pengolahan sampah. Oleh karena itu kedua komponen tersebut perlu memperoleh perhatian khusus pada siklus II.

Hal yang akan dilakukan untuk memperbaiki hasil refleksi siklus I adalah mengefektifkan fungsi kontrol oleh kepala sekolah dan melibatkan para pedagang 
makanan/minuman dan para pengelola kantin untuk melaksanakan kebersihan sehabis istirahat sekolah.

\section{Deskripsi Hasil Siklus II}

Hasil refleksi/analisis data yang telah dilakukan peneliti pada siklus I dijadikan sebagai acuan untuk melakukan perencanaan, pelaksanaan, observasi, dan refleksi pada siklus II dengan memperbaiki kelemahan-kelemahan yang ada pada siklus I. Kegiatan-kegiatan tersebut adalah sebagai berikut.

Perencanaan Tindakan

Pada tahap ini peneliti melakukan persiapan-persiapan yang berhubungan dengan halhal sebagai berikut.

1) Menyusun rencana kegiatan tindakan, yang berupa penyiapan perangkat penelitian

2) Mengadakan sosialisasi terhadap para siswa, guru, dan keluarga besar sekolah tentang pelaksanaan tindakan tersebut.

3) Mengundang para pedagang yang menjual makanan/minuman di sekitar sekolah dan mengundang para pengelola kantin sekolah untuk dilibatkan dalam pelaksanaan kebersihan setelah istirahat sekolah habis.

\section{Pelaksanaan Tindakan}

Tindakan yang dilakukan pada tahap pelaksanaan tindakan ini adalah sebagai berikut.

1) Melaksanakan fungsi kontrol dalam penerapan $3 R$

2) Melibatkan para pedagang makanan dan minuman serta para pengelola kantin sekolah untuk ikut melaksanakan kebersihan setelah setiap habis istirahat sekolah. Observasi

Hasil pengamatan pada akhir siklus II menunjukkan bahwa pada siklus II kondisi 7K di SMP negeri 1 Tegowanu Kabupaten Grobogan secara umum mengalami peningkatan. Rata-rata yang diperoleh seluruh komponen adalah 81,36. Refleksi

Dari hasil pengamatan pada pada siklus I dan pada siklus II, kondisi $7 \mathrm{~K}$ di SMP Negeri 1 Tegowanu menunjukkan bahwa secara umum telah terjadi peningkatan 
7K antara kondisi akhir siklus I dan pada kondisi akhir siklus II. Peningkatan tersebut sebesar 15,45\%. Ini merupakan kenaikan yang cukup signifikan. Bila dihitung secara statistik, peningkatan $7 \mathrm{~K}$ pada kondisi awal sebelum diberi tindakan dengan kondisi pada akhir siklus II adalah 33,18\% ditambah 15,45\% sama dengan 48,63\%.

Bila dituangkan dalam bentuk grafik, kondisi 7K di SMP Negeri 1 Tegowanu dilihat dari kondisi awal sebelum diberi perlakuan/tindakan, pada akhir siklus I, dan pada akhir siklus II adalah seperti berikut ini.

\section{Grafik Peningkatan 7K pada Kondisi Awal, Siklus I dan Siklus II}

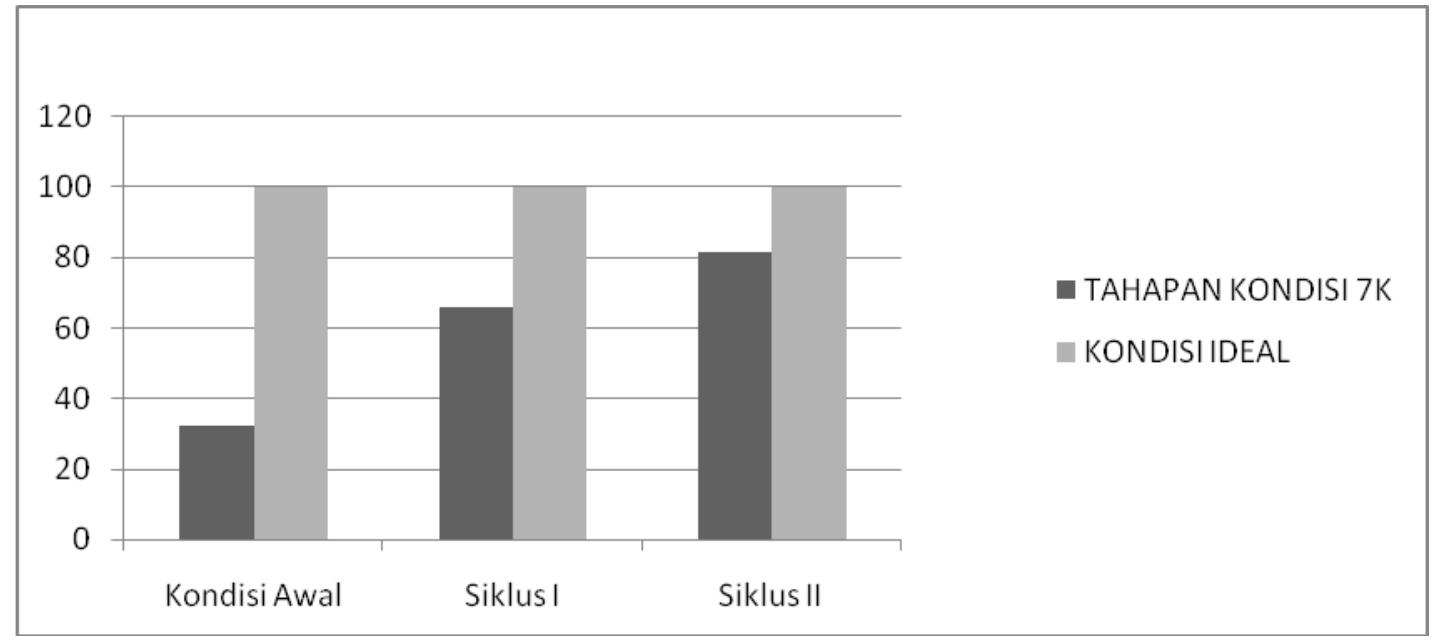

Terdapat komponen yang tidak mengalami kenaikan, yaitu komponen pengolahan sampah plastik. Karena tidak terjadi kegiatan pengolahan sampah plastik, maka hasil dari kegiatan pengolahan sampah plastik pun tidak ada. Hal yang perlu dipikirkan oleh pengelola sekolah di masa yang akan dating adalah mencari terobosan baru agar kegiatan pengolahan sampah plastik ini dapat terlaksana. Langkah yang dapat dilakukan adalah bekerjasama dengan pihak ketiga, atau mengirim guru keterampilan untuk mengikuti pelatihan pengolahan sampah pada dinas atau instansi terkait. 


\section{Perubahan 7K di Sekolah}

Setelah diadakan perlakuan tindakan melalui penerapan 3R di SMP Negeri 1 Tegowanu, kondisi 7K meningkat dengan cukup signifikan. Dalam hal kebersihan telah mengalami perubahan yang luar biasa. Sampah-sampah tidak terlihat lagi berserakan di sembarang tempat. Sampah plastik yang biasanya berhamburan di setiap sudut halaman sekolah, kini sudah tidak terlihat lagi.

Para siswa dan guru telah terbiasa membeli makanan dan minuman dengan menggunakan piring dan gelas masing-masing. Mereka memiliki piring dan gelas yang disimpan di kelas masing-masing. Hal lain yang membanggakan adalah di tiaptiap kelas telah terpasang galon air putih, sebagai minuman mereka. Pengadaan sarana termasuk biaya isi ulang gallon tersebut menjadi tanggung jawab kelas, dengan mengadakan uang kas kelas.

Hasil pengolahan sampah (daur ulang) di sekolah yang dilakukan oleh para siswa dengan bimbingan guru, telah berlangsung dengan baik. Hasil daur ulang kertas berupa kertas daur ulang, disimpan di ruangan khusus. Kelak di kemudian hari akan bekerjasama dengan pihak ketiga untuk pemasarannya. Demikian juga dengan hasil daur ulang sampah daun (organik) diolah menjadi kompos. Ke depan juga akan bekerjasama dengan para petani atau penjual tanaman hias untuk pemasarannya.

Sebagai bukti bahwa pelaksanaan 7K di SMP Negeri 1 Tegowanu telah meningkat, adalah dengan diperolehnya prestasi sekolah dalam bidang lingkungan bersih dan sehat, yaitu:

a. Juara I Lomba Sekolah Sehat tingkat Kabupaten Grobogan tahun 2010/2011

b. Juara II Lomba Sekolah Sehat tingkat Eks-Karesidenan Semarang Tahun 2010/2011.

c. Pelaksana Terbaik Kedua Sekolah Peduli dan Berbudaya Lingkungan tingkat Provinsi Jawa Tengah Tahun 2010/2011

d. Menjadi Calon Sekolah Adiwiyata tingkat Nasional tahun 2010/2011 


\section{PENUTUP}

\section{Simpulan}

Berdasarkan pembahasan hasil penelitian yang telah diuraikan di depan, maka hasil penelitian ini dapat disimpulkan sebabai berikut (1) Melalui penerapan program kegiatan 3R (Reuse, Reduce, dan Recycle) ternyata dapat meningkatkan 7K di SMP Negeri 1 Tegowanu Kabupaten Grobogan; (2) Peningkatan 7K setelah diberikan perlakuan atau tindakan melalui program kegiatan 3R (Reuse, Reduce, dan Recycle) di SMP Negeri 1 Tegowanu dari kondisi awal sampai dengan siklus I adalah sebesar $33,18 \%$. Sementara itu kenaikan dari siklus I ke siklus II adalah sebesar 15,45\%. Sedangkan bila dibandingkan antara kondisi awal sebelum diadakan tindakan dengan akhir siklus II adalah sebesar 48,63\%; dan (3) Sebagai bukti bahwa pelaksanaan 7K di SMP Negeri 1 Tegowanu telah meningkat, adalah dengan diperolehnya prestasi sekolah dalam bidang lingkungan bersih dan sehat, yaitu:

a. Juara I Lomba Sekolah Sehat tingkat Kabupaten Grobogan tahun 2010/2011

b. Juara II Lomba Sekolah Sehat tingkat Eks-Karesidenan Semarang Tahun 2010/2011.

c. Pelaksana Terbaik Kedua Sekolah Peduli dan Berbudaya Lingkungan tingkat Provinsi Jawa Tengah Tahun 2010/2011

d. Menjadi Calon Sekolah Adiwiyata tingkat Nasional tahun 2010/2011

\section{Saran dan Rekomendasi}

Berdasarkan simpulan hasil penelitian di atas, saran-saran dan rekomendasi yang dapat disampaikan dalam laporan hasil penelitian ini adalah sebagai berikut (1) Para kepala sekolah dianjurkan untuk dapat menerapkan program 3R (Reuse, Reduce, dan Recycle) untuk meningkatkan 7K di sekolah; (2) Para guru, siswa, dan para penanggung jawab $7 \mathrm{~K}$ di sekolah disarankan untuk secara kontinyu mengelola sampah, untuk membantu mewujudkan sekolah yang bersih, asri, indah, dan nyaman untuk berlangsungnya proses pembelajaran; dan (3) Kegiatan pembiasaan terhadap 
para siswa dan guru dalam melaksanakan 3R di sekolah agar senantiasa dipertahankan, dilestarikan, dan dikembangkan secara terus-menerus. Sebab kegiatan pembiasaan diperlukan waktu yang relatif lama dan dilaksakan secara berkesinambungan. Bila kegiatan pembiasaan tidak dilaksanakan secara berkesinambungan, maka kegiatan pembiasaan tersebut tidak akan berhasil.

\section{DAFTAR PUSTAKA}

Alamendah. 2010. 3R (Reuse Reduce Recycle) Sampah. http://guru-indonesia.net/ forum/forum topik isi-135.html. diunduh tanggal 1 Juli 2010.

Arikunto, Suharsimi. 1996. Administrasi Pendidikan untuk Sekolah Menengah Kejuruan. Jakarta: Rineka Cipta.

Arikunto, Suharsimi,Suhardjono, Supardi. 2009. Penelitian Tindakan Kelas. Jakarta: PT. Bumi Aksara.

Arikunto, Suharsimi. 2010. Penelitian Tindakan. Yogyakarta: Aditya Media.

Aqib, Zaenal. et all. 2008. Penelitian Tindakan Kelas, untuk Guru SMP, SMA, SMK. Bandung: Yrama Widya.

Aqib, Zaenal. 2009. Penelitian Tindakan Sekolah, untuk Pengawas Sekolah, Kepala Sekolah, dan Guru. Bandung: Yrama Widya.

Buku Panduan Adiwiyata, Sekolah Peduli dan Berbudaya Lingkungan 2010, Kementerian Lingkungan Hidup Republik Indonesia.

Burhanudin. 1990. Pengukuran dan Penilaian Pendidikan. Bandung: Tarsito.

Darmawan, M. 2010. Reduce, Reuse, Recycle + Repair. http://akuinginhijau.org/ 2007/ 08/06/ reduce-reuse-recycle-repair/. diunduh 15 Juni 2010.

Dinas Kesehatan Kabupaten Grobogan. 2010. Visi dan Misi Dinas Pendidikan Kabupaten Grobogan. file:///E:/ Visi \%20 Misi \%20\%20\%20 Dinas $\% 20$ Kesehatan \%20 Kabupaten \%20 Grobogan.htm. diunduh 15 Juni 2010.

Fasya, Helmi Farid. 2010. Sekolah Bersih, Nyaman Belajar. http://www.smakorpribekasi. sch.id/berita-127-sekolah-bersih-nyaman-belajar.html. diunduh 15 Juni 2010.

Moleong, Lexi J. 2010. Metodologi Penelitian Kualitatif. Bandung: PT Remaja Rosdakarya. 
Muslich, Masnur. 2009. Melaksanakan PTK Penelitian Tindakan kelas Itu Mudah. Jakarta: Bumi Aksara.

Nasution, S. 2009. Metode Research (Penelitian Ilmiah). Jakarta: Bumi Aksara.

Patton, Michael Quinn. 2009. Metode Evaluasi Kualitatif. Yogyakarta: Pustaka Pelajar.

Peraturan Menteri Pendidikan Nasional Republoik Indonesia Nomor 20 Tahun 2007 tentang Standar Penilaian.

Purwanto, M. Ngalim. 1998. Psikologi Pendidikan. Bandung: Remaja Rosdakarya.

Subyantoro. 2009. Penelitian Tindakan Kelas. Semarang: Badan Penerbit Universitas Diponegoro.

Sugiyono. 2010. Metode Penelitian Pendidikan, Pendekatan Kuantitatif, Kualitatif, dan R\&D. Bandung: Alfabeta.

Sukmadinata, Nana Syaodih. 2010. Metode Penelitian Pendidikan. Bandung: PT Remaja Rosdakarya

Supardi dan Suhardjono. 2009. Strategi Menyusun Penelitian Tindakan Kelas. Yogyakarta: Penerbit Andi.

Suryabrata, S. 1994. Psikologi Kepribadian. Yogyakarta: Kanisius.

Takari, R Enjah. 2010. Penelitian Tindakan Kelas. Bandung: PT Ganesindo.

Yulistyowati, Wiwik Ika. 2010. Sekolah Sehat. http://www.smpn120jakarta.com/ berita/ berita-sekolah/79-sekolah-sehat. diunduh 15 Juni 2010. 


\section{Biodata:}

Nama

NIP

Jabatan

Unit Kerja

Alamat rumah

Nomor telepon

Email

Pendidikan
: Hartanto, S.Pd.,MM.

: 196409301988031003

: Kepala Sekolah**)

: SMPN 1 Tegowanu, Kabupaten Grobogan**)

: Perum PGRI Blok L/55 Semarang

: $081326511001 / 024-76739783$

:pakhartanto64@yahoo.co.id

: S2 Manajemen SDM dan S2 Pendidikan Bahasa Indonesia

Unnes

(sedang menyelesaikan tesis)

**) Keterangan:

Saat penelitian ini dilakukan, ybs. menjabat sebagai Kepala SMP Negeri 1 Tegowanu, tetapi sejak tanggal 1 Maret 2012 ybs. menduduki jabatan baru sebagai Pengawas Sekolah Bidang Dikmen di Dinas Pendidikan Kabupaten Grobogan. 